\title{
Brotéria and the Popularization of Science, Technology, and Medicine in Portugal, 1907-24
}

\author{
Francisco Malta Romeiras \\ CIUнст, Universidade de Lisboa \\ franciscomesquitella@gmail.com
}

\begin{abstract}
Brotéria was founded in 1902 as a taxonomy journal of a small Jesuit college in the interior of Portugal. Because the revenue from individual subscriptions was insufficient to cover the costs of publication, Joaquim da Silva Tavares decided to create a magazine in 1907 called Vulgarização científica, which became very popular. Especially designed to make a profit, the journal published more than $45^{\circ}$ articles on agriculture, commerce, industry, chemistry, physics, medicine, and hygiene until 1924, and played a very significant role in disseminating knowledge of these subjects to a non-specialist Portuguese readership.
\end{abstract}

\section{Keywords}

Brotéria - Joaquim da Silva Tavares - history of science - popularization of science science and religion

In 1902, Joaquim da Silva Tavares (1866-1931), Cândido de Azevedo Mendes (1874-1943), and Carlos Zimmermann (1871-1950) started the publication of Brotéria, the first Jesuit periodical exclusively dedicated to science. ${ }^{2}$ The

1 This paper is an abridged version of a chapter in my monograph: Jesuits and the Book of Nature: Science and Education in Modern Portugal (Leiden: Brill, 2019).

2 The complete title of this journal in the opening issue was Brotéria: Revista de sciencias naturaes do Collegio de S. Fiel. However, it became known simply as Brotéria. On the scientific

(C) FRANCISCO MALTA ROMEIRAS, 2020 | DOI:10.1163/22141332-00702005

This is an open access article distributed under the terms of the prevailing CC-BY-NC-ND 4.0 license. 
journal borrowed its name from the Portuguese botanist Félix Avelar Brotero (1744-1828) and was printed in the Colégio de São Fiel (1863-1910), a small Jesuit boarding school in Louriçal do Campo, in the interior of Portugal. From 1902 to 2002, Brotéria published around 1,300 scientific articles covering a variety of fields, including botany, zoology, plant breeding, biochemistry, and molecular genetics. Its initial focus on identifying, describing, and classifying novel species collected in Portugal, Spain, Austria, Germany, Angola, Mozambique, Timor, Brazil, and Argentina played a significant part in the evolution of the botanical and zoological sciences, especially in the early decades of the twentieth century.

Between 1902 and 1906, Brotéria was directed at a broad academic audience. In order to ensure that the journal reached as wide a readership as possible, the Portuguese Jesuits exchanged their journal with more than a hundred national and international scientific magazines. But doing so also led to significant financial problems. As the journal specialized in identifying and classifying new species of animals and plants, its primary readership was made up of professional botanists and zoologists.; because these scientists directly collaborated with some of the journals that exchanged with Broteria, they could easily access the journal and, more importantly, they could do so for free.

At the same time, the number of paying non-academic subscribers was largely insignificant, which meant that the revenue from subscriptions was insufficient to cover the costs of publication. In 1907, to compensate for the lack of individual subscriptions, Silva Tavares restructured Brotéria by dividing it into three separate periodicals: the two scientific series, Botânica and Zoologia, and a popular scientific periodical, Vulgarização científica. The latter journal, which was written entirely in the vernacular, was directed at "less instructed people" and was designed to make a profit. ${ }^{3}$ The journal published more than

history of Brotéria, see Francisco Malta Romeiras, Jesuits and the Book of Nature: Science and Education in Modern Portugal (Leiden: Brill, 2019); Francisco Malta Romeiras and Henrique Leitão, "One Century of Science: The Jesuit Journal Brotéria (1902-2002)," in Exploring Jesuit Distinctiveness: Interdisciplinary Perspectives on Ways of Proceeding within the Society of Jesus, ed. Robert Maryks (Leiden: Brill, 2016), 235-58; and Francisco Malta Romeiras, "The Journal Brotéria (1902-2002): Jesuit Science in the 2oth Century," HoST:Journal for the History of Science and Technology 6 (2012): 100-9.

3 "Prólogo," Brotéria: Vulgarização científica 6 (1907): 5-9, here 7. Unlike the articles published in Vulgarização científica, the articles in the Zoologia and Botânica series were written in a multitude of languages, including Latin, Portuguese, German, English, French, and Spanish. The Jesuits used a variety of strategies to make a profit and cover the expenses of the scientific series. In 1919, Vulgarização científica began to include a plethora of advertisements in its initial pages for banks, hotels, typographies, factories, drugstores, bookstores, and jewelry stores. Beginning in the late 1920s, the support of benefactors seems to have been crucial as 
$45^{\circ}$ articles on chemistry, physics, agriculture, commerce and industry, medicine and hygiene, seismology, geography, and archaeology between 1907 and 1924, when it ceased publication, and it played an important role in disseminating knowledge of these subjects to a non-specialist Portuguese readership.

As well as publishing longer essays, Vulgarização científica also published shorter articles, including more than $35^{\circ}$ book reviews and over a thousand brief news reports referring not only to scientific novelties in agriculture, chemistry, physics, botany, zoology, and medicine but also to conferences, academies, and distinctions attributed to Portuguese scientists. ${ }^{4}$ The journal also contained a section dedicated to household matters, entitled "Useful Things," which welcomed articles with practical advice on a variety of household issues, including stain-cleaning, meat conservation, gold and bronze polishing, and soap manufacture. Sometimes, the Jesuits also gave medical advice on how to treat toothaches, coughs, or bronchitis. Readers seem to have particularly appreciated the culinary recipes published in this section. ${ }^{5}$ In late 1917, for instance, an anonymous reader living in Porto wrote to the editor asking for the publication of more "tasteful and practical culinary recipes" as Christmas was approaching and Vulgarização científica had not published any recipes in the former three issues. ${ }^{6}$ Because they wanted to attract young readers to their popular magazine, the Jesuits also published small inspirational novels in this series, including Percy Wynn: Or Making a Boy of Him (1893), one of the earlier works of American Jesuit Francis J. Finn (1859-1928). ${ }^{7}$ By publishing technical articles dedicated to a learned reader alongside culinary

well. For forty consecutive years (1927-67), the Jesuits printed a list of benefactors on the back cover of Brotéria, which included Jesuit alumni and a few notable personalities from the clerical and aristocratic spheres.

4 Marta Mendonça, "Brotéria e a difusão da ciência em Portugal," in Fé, ciência, cultura: Brotéria; 100 anos, ed. Hermínio Rico and José Eduardo Franco (Lisbon: Gradiva, 2003), 255-76, here $267-69$. The tradition of publishing book reviews can be traced back to the foundation of Brotéria. Between 1902 and 1906, Silva Tavares and his companions published 282 book reviews in the original series of Brotéria. After the restructuration, the three independent series continued to include book reviews in their issues. Overall, between 1907 and 1924, Botânica, Zoologia, and Vulgarização científica published 853 book reviews.

5 See especially Lena, "Arte culinária," Brotéria: Vulgarização científica (henceforth BVC) 14 (1916): 108-10, 174-75, 227-28, 286-87, 334-35; Lena, "Arte culinária," BVC 15 (1917): 31-32, 9091, 171-72; Lena "Arte culinária," BVC 16 (1918): 1-2.

6 The letter was included in a short reply by Silva Tavares, who signed under a pseudonym. See Dionel, "Ás leitoras da Brotéria," вVC 16 (1918): 5.

7 The novel was published as a booklet between November 1915 and May 1916. 


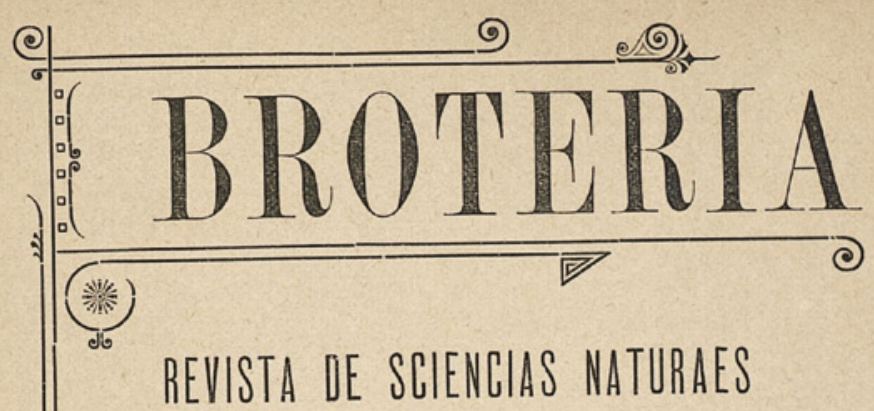

DO COLLEGIO DE S. FIEL

(2)irigida

PELO PROFESSOR

Joaquim da Silva Tavares

1907

V $\quad 1907$

III PARTE

SERIE DE VULGARIZAÇÃO SCIENTIFICA

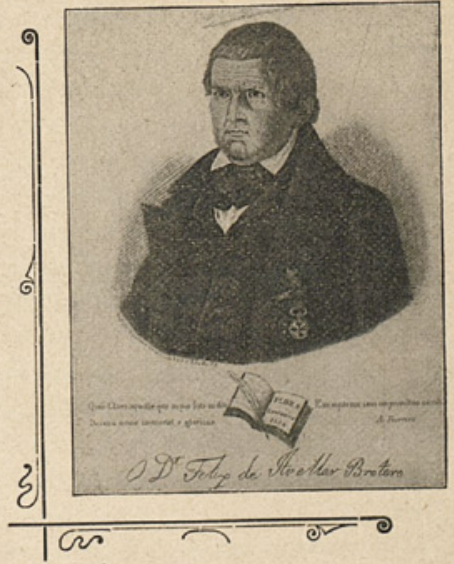

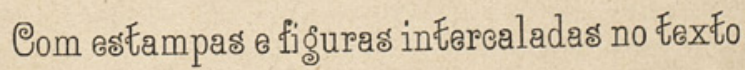

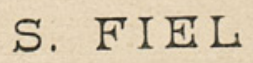

1907

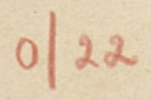

FIGURE 5.1 First issue of Brotéria: Vulgarização científica, 1907 
recipes, novels, and household counsels, Silva Tavares and his companions hoped to broaden the appeal of their magazine and thus cover the expenses of the more specialized scientific series.

Because it was conceived as popular magazine, Vulgarização covered a large variety of subjects, including history, sociology, ethnography, archeology, history of science, and pedagogy. However, the sections on agriculture, physics, geography, commerce, industry, medicine, and hygiene were clearly predominant, accounting for about sixty-nine percent of all popular articles. The vast majority of the lengthier articles were written by da Silva Tavares and a few other Jesuits, especially Camilo Torrend (1875-1961), Cândido de Azevedo Mendes, António de Oliveira Pinto (1868-1933), Raúl Sarreira (1889-1968), Manuel Rebimbas (1873-1944), Manuel Narciso Martins (1858-1940), and Artur Redondo (1873-1966). Yet, Vulgarização científica also welcomed articles by laymen, including the celebrated chemist António Ferreira da Silva (18531923), and physicians José Pedro Dias Chorão (1853-1928) and Fernando de Almeida e Silva (1873-1942).

However, of all these authors, it was Silva Tavares who featured most prominently. The founder and editor-in-chief of Brotéria was deeply invested in the popular series for many reasons, but the financial aspect seems to have been the most important. Ensuring Vulgarização científica's commercial success was not a minor issue because it was a sine qua non condition for the publication of Botânica and Zoologia, which were already acknowledged as significant publications in their respective fields. This meant that, besides working systematically in the classification of plant galls around the globe, Silva Tavares dedicated a considerable part of his time to writing popular articles for the series. Between 1907 and 1924, for instance, he alone published 174 articles, which accounts for more than forty percent of all articles published in the popular series. ${ }^{8}$

\subsection{Agriculture, Commerce, and Industry}

The largest section in Vulgarização científica was on agriculture. ${ }^{9}$ The first article, by Jesuit Manuel Martins, was published in 1908 and focused on a highly important topic, agricultural plagues. Given that corn was an essential cereal to feed the "dense population" of northern Portugal, Martins's intention was to

8 Silva Tavares and Torrend, the two most prolific authors of Vulgarização científica, published a total of 213 articles, that is, about fifty percent of all articles. Silva Tavares sometimes published under the pseudonyms Dionel and Tessa.

9 Between 1908 and 1924, the popular series published seventy-two articles on agriculture (approximately 16.8 percent of all articles). 


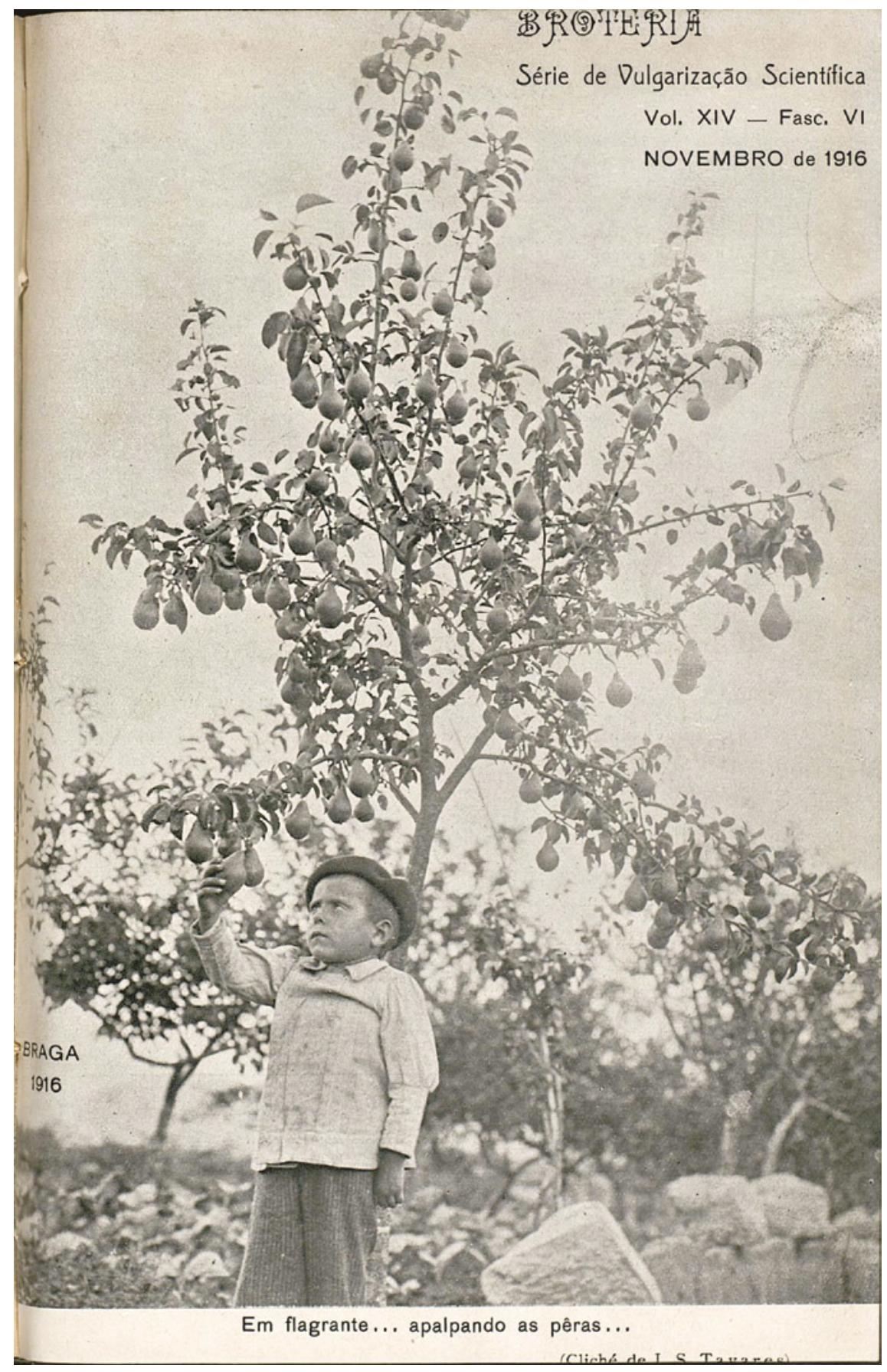

FIGURE 5.2 Brotéria: Vulgarização científica, November 1916 
provide the most effective means to combat the parasites that prevented corn from being harvested or conserved. For him, it was vital to eradicate such plagues because without corn "those good peasants would be forced to migrate" to "distant and insalubrious lands in search for their daily sustenance."10 In subsequent years, Vulgarização científica's correspondents also wrote several articles on the production of wheat, soy, sugar, coffee, cocoa, wine, cotton, wool, and rubber. ${ }^{11}$ The articles on wheat and wine focused on the Portuguese context. A few years later, the pursuit of food independence-in which wheat would play a key role-became one of the most pressing issues for the dictatorial Estado Novo regime. ${ }^{12}$ In turn, the publication of articles on vegetal byproducts that were important for the Brazilian economy - particularly sugar, coffee, and cocoa-reflected the need to reach a wider readership during the Jesuits' exile, as while Silva Tavares and his companions were in Baía (1912-15), Brotéria depended almost exclusively on Brazilian subscribers. ${ }^{13}$

Like the agricultural section, the section dedicated to commerce and industry focused on the trade of Portuguese and Brazilian goods, namely fruit, rubber, cocoa, coffee, cereals, and dairy. Given its importance for the national economy, Brotéria also welcomed articles on the trade of cork and wine. ${ }^{14}$ Among these articles, the most relevant was perhaps the piece by Ferreira da

$10 \quad$ Manuel Narciso Martins, "O milho grosso em Portugal e seus inimigos," BVC 7 (1908): 6883, here 73 .

11 See especially the following articles: Joseph Foulquier, "A borracha brazileira," BVC 12 (1914): 5-31; Joaquim da Silva Tavares, "A producção do assucar brasileiro," BVC 12 (1914): 282-95; Tavares, "Producção mundial de lã e particularmente nas colónicas britânicas," BVC 12 (1914): 305-7; Florentino Barbosa, "O café na Parahyba," BVC 12 (1914): 347-50; Camilo Torrend, "A cultura do algodão," $B V C 14$ (1916): 5-12; 82-89; 137-45; J. M. da Cunha, "A produção de trigo em Portugal em 1923," BVC 22 (1924): 135-36; J. M. da Cunha, "A colheita do vinho nos principais países produtores em 1923: O vinho português em 1923," BVC 22 (1924): 137-39; António Monteiro Filipe, "Notas sobre a cultura do cacau em S. Tomé," BVC 18 (1920): 174-80; Joaquim da Silva Tavares, "A cultura da soja," BVC 22 (1924): 29-34; Camilo Torrend, "A cultura do cacau," BVC 16 (1918): 12-19; 82-91; 128-35; 175-83; 274-80; Torrend, "A cultura do cacau," вVC 17 (1919): 23-28, 41-46; 106-14; 128-38.

12 Tiago Saraiva, Fascist Pigs: Technoscientific Organisms and the History of Fascism (Cambridge, MA: MIT Press, 2016), 43-70.

13 Tavares, "A Brotéria nos primeiros 25 anos da sua existência," 35.

14 On the trade in wine, see especially "A producção vinicola em Portugal em 1913," BVC 12 (1914): 313-15; "Exportação do vinho pela barra do Porto em 1913," BVC 12 (1914): 315; Joaquim da Silva Tavares, "A producção vinicola em Portugal em 1915," BVC 14 (1916): 188-89; Tavares, "O vinho português em 1916," BVC 15 (1917): 91-95. On the production of and commerce in cork, see Joaquim da Silva Tavares, “A cortiça portuguesa," BVC 15 (1917): 53-65; A. Vieira Novo, "A indústria corticeira," BVC 21 (1923): 207-12. 
Silva, from the Polytechnic Academy of Porto. ${ }^{15}$ From the 189os, he was arguably the most prominent Portuguese chemist, partly due to his decisive role in the well-known controversies between the Brazilian and Portuguese governments over the adulteration of Port wine exported to Brazil in 1894 and again in 1900. The dispute was of paramount importance for both political and economic reasons. The Clinical Laboratory of Rio de Janeiro argued that the recently imported Port wine had been seriously tainted with salicylic acid, which sweetened the wine and artificially augmented its durability. This was indeed a very serious accusation, because it could hinder the trade of Port wine with Brazil and, most importantly, with England. ${ }^{16}$ After analyzing the exported wine, Ferreira da Silva argued that the content of salicylates was residual and that it had not been caused by any kind of adulteration; instead, the change was a byproduct of the natural process of fermentation. ${ }^{17}$ The crown acknowledged his services by making him peer of the realm and advisor to the king.

Ferreira da Silva briefly described the processes of Port wine manufacture in Vulgarização científica from harvest to aging and bottling and presented and analyzed the most important figures in the trade of Port wine from 1678 onward. Interestingly, he did not address what had been the most pressing issue in the previous decades, the 1894 and 1900 controversies. Ferreira da Silva's article aimed to disseminate the most basic concepts on the manufacture and commerce of Port wine to a Portuguese readership. As a renowned expert in the field, his principal goal was to explain technical issues as simply as possible, without compromising the scientific objectivity of the concepts and processes at hand. By publishing an article in Vulgarização científica on this issue, Ferreira da Silva consequently lent his scientific credibility and expertise to the Jesuits' journal, with its publication testifying, once again, to the close friendship between the chemist and the Jesuit naturalists.

15 António Ferreira da Silva, “Os vinhos do Porto," BVC 13 (1915): 129-39; 181-95.

16 The trade in Port wine was of paramount importance for the Portuguese crown. In 1703, the Portuguese and English crowns had signed a commercial treaty, commonly referred to as Methuen Treaty, which favored both the export of Port wine and the import of British woolen cloth.

17 Ferreira da Silva published extensively on the controversy surrounding the adulteration of Port wine. Based on his personal notes, he published a very useful summary of the controversy. See António Ferreira da Silva, A suposta salicilagem dos vinhos portugueses no Brasil (1900-1902): Memórias, notas e documentos (Coimbra: Imprensa da Universidade, 1919). For more details, see especially Jorge Fernandes Alves and Rita C. Alves, A. J. Ferreira da Silva: Nos caminhos da química (Porto: Universidade do Porto, 2013). 


\subsection{Geography}

Between 1907 and 1917, the vast majority of the articles on geography aimed to disseminate historical and geographical facts about South American cities and provinces. The inclusion of a considerable number of photographs in these articles, as well as the simple prose, testified to the importance of geography in the broader program of popularization designed by the Jesuits. ${ }^{18}$ As in the case of agriculture, Silva Tavares wrote several articles for this section based on his visits to urban and rural regions during his exile in Brazil, Argentina, and Spain, with his notes being published in the pages of Vulgarização científica. ${ }^{19}$ By resourcefully combining his enthusiasm for photography with the situation in which he found himself, Silva Tavares offered his readers a copiously illustrated memoir of his exile. Along with essays on specific cities, the geography articles also addressed coetaneous economic issues, such as the construction of the Panama Canal and the financial implications of granting the monopoly on transatlantic communication to the United States. ${ }^{20}$

The successful relocation of Brotéria to Spain in 1914 led to some changes in the editorial policy of Vulgarização científica. Beginning in 1918, the geographical section shifted its focus from Brazil to Portugal, with articles on illiteracy rates, criminality, census data, and the cost of living. In other words, the essays began to address educational, economic, and demographic issues that were of particular interest for a learned Portuguese readership. ${ }^{21}$ However, the topic that interested Silva Tavares the most in this period was fisheries, especially in

18 Between 1907 and 1924, Vulgarização científica published sixty-one articles on geography (around 14.2 percent of all articles).

19 Joaquim da Silva Tavares, "A Argentina: Impressões de um excursionista," BVC 11 (1913): 350-69; Tavares, "A cidade de Santos," BVC 10 (1912): 101-38; Tavares, "O Corcovado," BVC 10 (1912): 189-99; Tavares, "Uma excursão a Minas," BVC 11 (1913): 126-62; Tavares, "Capital modelo: Bello Horizonte," BVC 12 (1914): 65-107; Tavares, "Maceió, capital do Estado de Alagoas," BVC 13 (1915): 324; Tavares, "Victória, capital do Estado do Espírito Santo," BVC 14 (1916): 16; Tavares, "A cidade de Parahyba do Norte," BVC 14 (1916): 81; Tavares, "Florianópolis, capital do Estado de Santa Catharina," BVC 14 (1916): 145-46; Tavares, "Uma cidade encantada no Estado do Paraná," BVC 14 (1916): 201-9; Tavares, "O salto de Iguaçu (Estado do Paraná)," BVC 14 (1916): 258-71.

20 J. Alves Matheus, "O Canal de Panamá e as outras vias de comunicação entre os dois oceanos," BVC 11 (1913): 178-80.

21 Joaquim da Silva Tavares, "O analphabetismo em Portugal," BVC 16 (1918): 111-20; 151-64; 229-36; Tavares, "A criminalidade em Portugal," BVC 17 (1919): 114-17; Tavares, "A carestia da vida em Portugal," BVC 20 (1922): 142-49; Tavares, "O censo da população portuguesa feito em Dezembro de 1920," BVC 22 (1924): 207-16. 


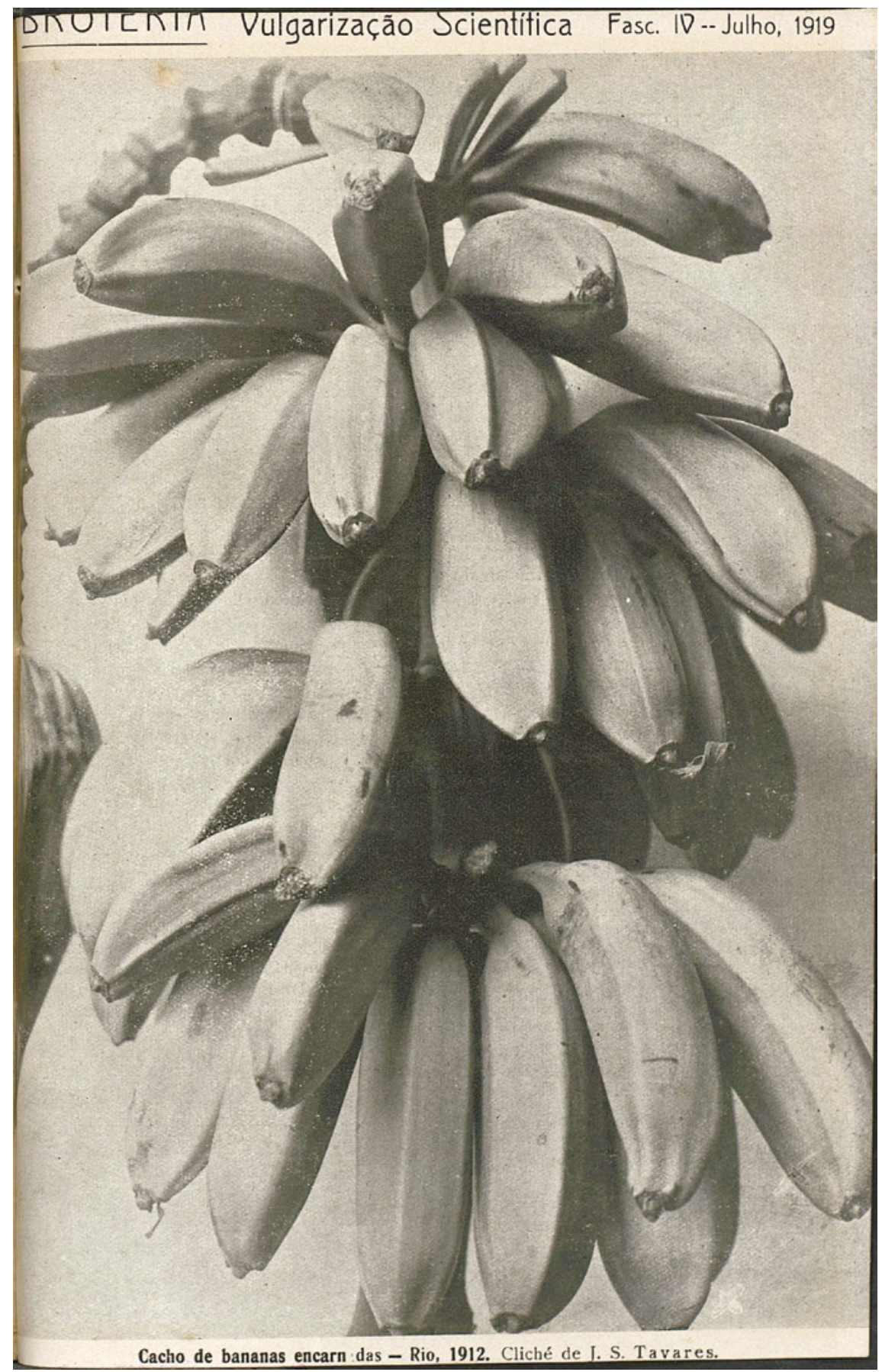

FIGURE 5.3 Brotéria: Vulgarização científica, July 1919 
the Minho River in northern Iberia. ${ }^{22}$ While the first geography articles were mostly descriptive, the articles on fisheries included some suggestions on how to address specific problems. Rather than just disseminating knowledge in a simpler, abridged version to a less familiar audience, Silva Tavares engaged with the reader and presented his own conclusions. ${ }^{23}$ After displaying and analyzing the official Portuguese and Spanish data on fisheries between 1920 and 1923, the editor-in-chief of Brotéria concluded that temperature and water purity were the two most decisive factors in determining the abundance or shortage of fish for a given year. In response to the shortage of salmon and allis shad in the Minho River, he urged for the creation of an Iberian laboratory of ichthyology—established either in Spain or Portugal—in order to reduce the costs involved in rearing these expensive species, promote their consumption by poorer rural populations, and improve the local economy. ${ }^{24}$ Similar to the articles on agriculture, commerce, and industry, the later articles on Portuguese and Spanish geography insisted on the importance of food independence and economic sustainability. Considered together, these topics constituted a basso continuo in the Jesuit program of popularization.

\section{$2 \quad$ Chemistry and Physics}

Whereas the articles on geography, agriculture, and commerce were easily understood, the early articles on chemistry, physics, and seismology addressed

22 Joaquim da Silva Tavares, "A pesca no Rio Minho," BVC 18 (1920): 262-76; Tavares, "A pesca no Rio Minho," BVC 19 (1921): 21-40; Tavares, "A pesca do atum em Portugal," BVC 20 (1922): 15-17; Tavares, "A pesca no Rio Minho em 1921," BVC 20 (1922): 19-23; Tavares, "A pesca no Rio Minho em 1922," BVC 21 (1923): 57-6o; Tavares, "As pescarias no Rio Minho em 1923," BVC 22 (1924): 89-95.

23 On the dominant view of popularization and the need to erase the distinction between the production and the transmission of knowledge for historical work, see especially Stephen Hilgartner, "The Dominant View of Popularization: Conceptual Problems, Political Issues," Social Studies of Science 20 (1990): 519-39; Roger Cooter and Stephen Pumfrey, "Separate Spheres and Public Spaces: Reflection on the History of Science Popularization and Science in Popular Culture," History of Science 32 (1994): 269-315; James Secord, "Knowledge in Transit," Isis 95 (2004): 654-72; and Bernadette Bensaude-Vincent, "A Genealogy of the Increasing Gap between Science and the Public," Public Understanding of Science 10 (2011): 99-113.

24 Tavares, "As pescarias no Rio Minho em 1923," 94-95. 
more technical issues. ${ }^{25}$ As such, it is likely that the readership of those articles was more circumscribed, because the articles presumed at least a certain familiarity with scientific instruments, theories, and practices. Given its increasing popularity and the recent ventures of António de Oliveira Pinto- the first Portuguese to work at Madame Curie's laboratory in 1910-it comes as no surprise that radioactivity emerged as one of the most discussed topics in the earlier chemistry articles (1907-17). ${ }^{26}$ From 1918 onward, applied chemistry gradually replaced theoretical chemistry, with Brotéria's correspondents, most notably Silva Tavares, paying more attention to matters of greater economic significance, namely the use of natural and artificial fuel in industry and in automobiles. ${ }^{27}$

As well as publishing articles directly related to the teaching of experimental physics, the Portuguese Jesuits were also concerned with contemporary debates on modern physics. Shortly after the famous expedition of Arthur Stanley Eddington (1882-1944) and Andrew Crommelin (1865-1939) to Principe and Brazil in 1919, for instance, Torrend wrote a short article for the Jesuits' magazine expounding the intention of the excursion (i.e., the possible confirmation of Albert Einstein's [1879-1955] theory of general relativity). ${ }^{28}$ In contrast to most previous expeditions, the focus of the observation was not the solar corona but a group of bright stars in the vicinity of the sun. The main objective of the British committee was to study the deflection of light emanating from those stars. By comparing two sets of photographs, before and after the eclipse of May 29, 1919, it would be possible to corroborate Einstein's

25 Between 1907 and 1924, Vulgarização científica published fifty-nine articles on physics, twenty-five on chemistry, and five on seismology (approximately 20.7 percent of all articles).

26 António de Oliveira Pinto, "O estudo da radioactividade da materia. Laboratorio de Giff," BVC 11 (1913): 51-68; António de Oliveira Pinto, "A radioactividade das aguas medicinaes de fraca mineralisação," BVC 13 (1915): 244-45; Manuel Rebimbas, "Radioactividade e gazes raros das fontes thermaes," BVC 7 (1908): 181-84.

27 Joaquim da Silva Tavares, "A substituição da gasolina nos automóveis," BVC 16 (1918): 7377; Tavares, "A substituição da gasolina nos automóveis pelo álcool," BVC 16 (1918): 239-40; Tavares, "O carvão líquido e a catálise: Vantagens industriais," BVC 20 (1922): 66-70; Tavares, "Origem da energia industrial: Gás natural, petróleo e carvão," BVC 21 (1923): 44-46.

28 Camilo Torrend, "O eclipse total de 29 de Maio de 1919, no Brazil," BVC 18 (1920): 40-41. Oddly miscategorized in the 1959 Index of Brotéria as a geography article, this article was in fact a popular article on physics: Índices gerais da Brotéria científica (1902-2002) (Lisbon: Brotéria, 2002), 144. 
theory. ${ }^{29}$ As Brotéria's article was written before the publication of Eddington's book on general relativity, Torrend presented and discussed the three possible outcomes. If there were no differences between the two sets of photographs, it would follow that light is not deflected by gravity. If, on the other hand, there was a deflection of seven-eighths of a second at the edge of the sun- -0.87 according to Eddington - then light was deflected according to Newtonian principles. But, if the deflection of light at the edge of the sun was twice that figure-1.74 in Eddington's account-then Einstein's theory would be proven correct. As Torrend anticipated, the "conclusion of this study will constitute an important development in the physical knowledge of the globe."30

Beginning in 1920, the vast majority of articles published in the physics section concerned aviation. ${ }^{31}$ This specific interest in aeronautics coincided with what historians have called the Golden Age of Aviation (1918-39), a period characterized by numerous technical developments in the manufacture of aircrafts and the increasing popularity of air racing and exploration. ${ }^{32}$ In the Portuguese context, the highpoint of the golden era was undoubtedly the venture of Carlos Gago Coutinho (1869-1959) and Artur de Sacadura Cabral (18811924), who crossed the South Atlantic Ocean for the first time in $1922 .{ }^{33}$ As was the case with the chemistry articles, the shift from theoretical physics to applied issues - developments in aviation, airplane commerce, and the first aerial circumnavigation-reflected the Jesuits' concern with reaching as wide a readership as possible.

29 Arthur Stanley Eddington, Space, Time and Gravitation: An Outline of the General Relativity Theory (Cambridge: Cambridge University Press, 1920), 110-22.

$30 \quad$ Torrend, "O eclipse total de 29 de Maio de 1919, no Brazil," 41.

31 Dionel, "Os progressos da aviação," BVC 18 (1920): 180-86; Dionel, "Aviação comercial," BVC 22 (1922): 29-39; A. Lamego, "A aviação ao serviço do comércio," BVC 20 (1922): 276-80; Lamego, "O voo à vela ou sem motor," BVC 20 (1922): 283-89; Lamego, "Heroísmo e aventuras da aviação em 1922," BVC 21 (1923): 131-34; Lamego, "Os progressos e serviços da aviação nos diferentes países," BVC 21 (1923): 163-74; Lamego, "Os aviões comerciais," BVC 21 (1923): 186-91; Lamego, "O voo à vela e suas causas," BVC 21 (1923): 267-70; Lamego, "Os páraquedas," BVC 22 (1924): 10-15; Lamego, "A volta ao mundo em avião," BVC 22 (1924): 74-77; Lamego, "Aeroplanos e suas aplicações," $B V C 22$ (1924):111-16; Lamego, "O esforço aeronáutico alemão," BVC 22 (1924): 216-23; Lamego, "As grandes viagens aéreas," BVC 22 (1924): $276-79$.

32 For the American context of the golden age of aviation, see especially Joseph J. Corn, The Winged Gospel: America's Romance with Aviation, 1900-1950 (New York: Oxford University Press, 1983), and Thomas Kessner, The Flight of the Century: Charles Lindbergh and the Rise of American Aviation (New York: Oxford University Press, 2010).

33 A. Vieira Novo, "A caminho do Brazil," BVC 20 (1922): 188-97; A. Lamego, "Heroísmo e aventuras da aviação em 1922," BVC 21 (1923): 131-34. 


\section{BROTERIA}

\section{Série de Vulgarização Scientífica}

\section{Vol. XIX - Fasc. IV - Julho de 1921}

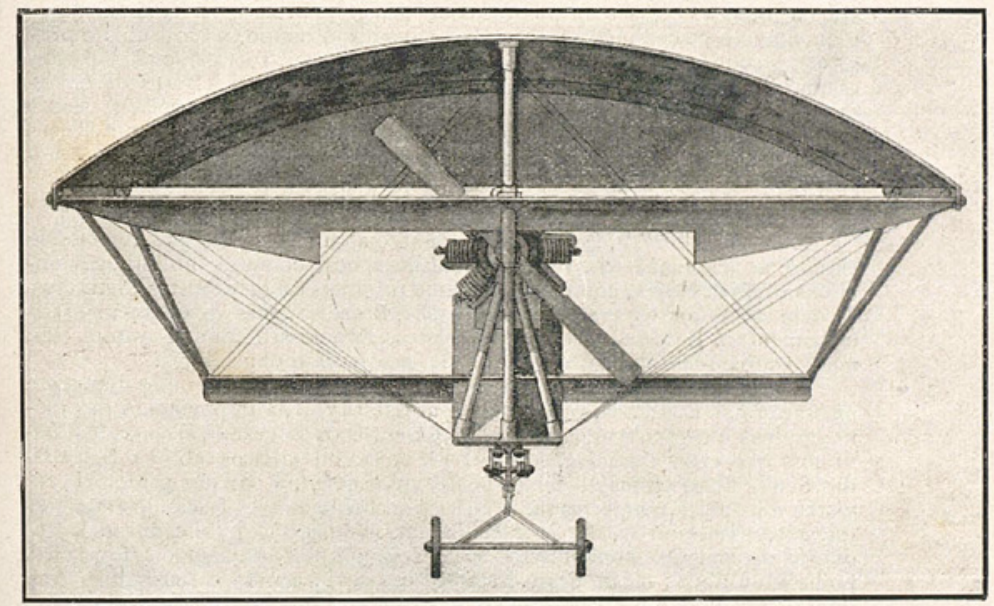

Um aeroplano paraquedas. De frente, em pleno vôo

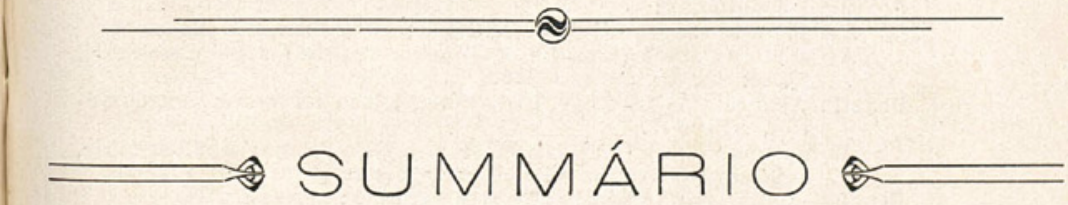

Um aeroplano paraquedas. Fruteiras do Brazil.Vitaminas, Béri-Béri e Escorbuto. Notícias breves. Coisas úteis. As lâmpadas eléctricas portáteis. $O$ oiro e a prata cm 1920 e 1921. A propósito dum livro recente: A. Eymieu, La part des croyants dans les progrés de la science au XIX.e siècle. Variedades.

Congresso Scientifico Luso-Espanhol.

FIGURE 5.4 Brotéria: Vulgarização científica, July 1921 
The articles on medicine and hygiene in Brotéria were almost exclusively written by physicians. Whereas the articles on hygiene addressed public health issues - such as eating practices, nicotine dependence, and alcoholism-the medical articles focused on the characterization and treatment of infectious diseases, including flu, meningitis, pneumonia, typhoid fever, leprosy, and syphilis. ${ }^{34}$ The sections on medicine and hygiene apparently followed a traditional model of popularization, because the articles were written by experts who sought to explain complex issues in the simplest prose. However, a closer inspection reveals that, once again, the boundaries between a popular magazine - that is, a journal directed to a broad, yet learned, audience — and a science journal — that is, a publication directed at peers - were rather fluid.

One of the most interesting examples of Vulgarização científica's fluidity was perhaps the work of physician José Pedro Dias Chorão, ${ }^{35}$ who published an important article in 1909 that reported the treatment of pneumonia in a student of São Fiel by means of an innovative procedure. ${ }^{36}$ The fourteen-year-old student had manifested the first symptoms on January 18, 1909. For Dias Chorão, it appeared to be a minor flu. On January 21, however, the physician confirmed that it was pneumonia, and with the new diagnosis, he proceeded to administer "hypodermic injections of dissociated [colloidal] silver" every six

34 Between 1907 and 1924, Vulgarização científica published forty-seven articles on medicine and hygiene (around eleven percent of all articles). For the hygiene section, see especially Manuel Rebimbas, "Noções de hygiene alimentar," вVc 6 (1907): 155-69; Paulino Vieilledent, "Perigos do tabaco," BVC 7 (1908): 151-54; José Pedro Dias Chorão, "O tabaquismo e o alcoolismo," $B V C 8$ (1909): 5-21; 41-57. For the medicine section, see José Pedro Dias Chorão, "Meningite cerebro-espinal epidémica," BVC 6 (1907): 50- 63; José Pedro Dias Chorão, "Gripe," BVC 6 (1907): 239-61; Chorão, "Febre typhoide: Prophylaxia e therapeutica," BVC 12 (1914): 115-22; 235-43; Chorão, "Um flagello social: A syphilis," BVC 13 (1915): 65-74; Alejo Diz, "O tifo exantemático," BVC 16 (1918): 140-44; José Pedro Dias Chorão, "A epidemia gripal de 1918 no concelho do Fundão," BVC 17 (1919): 66-75; Júlio Marinho, "Tratamento da lepra," BVC 22 (1924): 34-36.

35 There is not much written about this physician. Born in Capinha, a small village in the interior of Portugal, Dias Chorão practiced medicine in Fundão. As a local physician, he also served the Colégio de São Fiel. For a short biography, see Joaquim Candeias da Silva, "Evocação/Memória de alguns médicos notáveis da Beira Interior: Concelho do Fundão (v)," Medicina na Beira Interior da Pré-História ao século XX: Cadernos de cultura 20 (2006): $70-76$.

36 José Pedro Dias Chorão, "A prata dissociada pela corrente electrica, no tratamento da pneumonia," BVC 8 (1909): 97-99; 251-56. 
hours. ${ }^{37}$ The boy's general condition began to improve on January 22, and five days later, he was out of risk. ${ }^{38}$ As this method had proven successful two years earlier, when he treated a sixty-one-year-old patient, Dias Chorão was mostly interested in communicating to his peers how to use colloidal silver in the treatment of pneumonia. His article went on to describe the procedure and instruments that had been used to obtain the valuable solution. ${ }^{39}$ Later that year, Dias Chorão reported he had encountered three new cases of pneumonia and one case of an infection of the uterus, which had also been cured by means of colloidal silver. ${ }^{40} \mathrm{He}$ concluded that the "dosage of solute" could play a vital role in the treatment of pneumonia, as one infection only yielded after increasing the concentration of colloidal silver three times. ${ }^{41} \mathrm{He}$ was also able to identify at least two genera of bacteria that were responding to this treatment, Streptococcus and Staphylococcus. ${ }^{42}$ By applying the same procedure to the treatment of a severe infection of the uterus, which was seriously endangering a poor woman's life, Dias Chorão concluded that colloidal silver offered a promising method to fight infections, particularly "all infections of Streptococcus and Staphylococcus." ${ }^{43}$ For its usefulness, this article could be seen as a popular article, in a traditional sense. However, Dias Chorão was trying to communicate with his peers, and, for that reason, he provided all data he collected, described in detail the experimental procedure to obtain colloidal silver, and exhorted the medical community to use this method in the treatment of specific infections.

Four years later, in 1913, Dias Chorão explained how he had arrived at the idea of using colloidal silver to treat infections ${ }^{44}$ after reading a "very brief note" in the pages of Revue de thérapique (Review of therapeutics). However, the note was "so brief" that it did not give any details on how to obtain colloidal metals. Because he visited São Fiel frequently as a physician, he was able to ask professor of physics Valério Cordeiro (1877-1940) to design a procedure to obtain the coveted solution. ${ }^{45}$ After several failed attempts, Cordeiro decided to use an Oudin coil, an instrument frequently used in solemn sessions of the

\footnotetext{
37 Chorão, "A prata dissociada pela corrente electrica," 97.

38 Chorão, "A prata dissociada pela corrente electrica," 98.

39 Chorão, "A prata dissociada pela corrente electrica," 99.

40 Chorão, "A prata dissociada pela corrente electrica," $251-56$.

41 Chorão, "A prata dissociada pela corrente electrica," 252.

42 Chorão, "A prata dissociada pela corrente electrica," 255.

43 Chorão, "A prata dissociada pela corrente electrica," 256.

44 José Pedro Dias Chorão, "Os metaes coloidaes electricos na therapeutica," BVC 11 (1913): $40-50$.

45 Chorão, "Os metaes coloidaes," 40.
} 
scientific academy of São Fiel. Before using it for the first time, Dias Chorão had tried to scrutinize the medical benefits of colloidal silver, but it was only in 1912 that someone "courteously loaned" him a book on this particular subject. ${ }^{46}$ In his 1913 article, Dias Chorão summarized the findings of two physicians, which confirmed the efficacy of using colloidal metals in the treatment of myriad diseases, including rheumatism, flu, smallpox, syphilis, meningitis, and diphtheria. ${ }^{47}$ In addition to illustrating the tight connection between the teaching and practice of science at São Fiel, this example also reveals how particular medical practices could emerge in rural twentieth-century Portugal. Practical knowledge and experimentation superseded authoritative, though modern, theoretical knowledge.

Following in the footsteps of Dias Chorão, a few other physicians collaborated in the Jesuits' project of popularization. Possibly by suggestion of his close friend, former colleague at the University of Coimbra, and Jesuit alumnus António Egas Moniz (1874-1955), Portuguese physician Fernando de Almeida e Silva applied for a position in Fundão in October 1899. In April 1900, after being officially appointed as a local physician, he moved to the village and established a clinic. ${ }^{48}$ In 1908, he published an article on the process of baking bread and on the medical benefits of dark rye flour. ${ }^{49}$ Although he was a member of the editorial team of Vulgarização científica and physician at São Fiel, this turned out to be his only contribution to the Jesuits' popular magazine. As a friend of the Jesuits, he was probably expected to have published a few more articles in Brotéria, but the expulsion of the Jesuits from Portugal in 1910 will almost certainly have hindered this venture.

During his first years in Brazil, Silva Tavares sought to find new authors for both the scientific and the popular series. Brazilian physicians Cândido de Mello Leitão (1866-1948) and Egas Moniz Barreto de Aragão (1870-1924) and Spanish physician Alejo Diz (1885-1936) willingly accepted the invitation to write a few articles for the medicine and hygiene sections. As with the earlier articles, the main aim of these papers was to provide practical solutions to

46 Albert Robin, Les ferments métalliques et leur emploi en thérapeutique (Paris: J. Rueff Éditeur, 1907).

47 Louis Bousquet and H. Roger, Les métaux colloïdaux en thérapeutique (Paris: Masson, 1910).

48 Joaquim Candeias da Silva, "Evocação/Memória de alguns médicos notáveis da Beira Interior: Concelho do Fundão (IV)," Medicina na Beira Interior da Pré-História ao século XX: Cadernos de cultura 19 (2005): 83-88, here 85. Often referred to as Fernando d'Almeida (or de Almeida), Fernando de Almeida e Silva was son to papal count António de Almeida e Silva (1822-1900) and Maria Raquel Carvalho (1832-1911).

49 Fernando de Almeida, "O pão sob o ponto de vista hygienico," BVC 7 (1908): 9-39. 
everyday problems. When he wrote about baby-feeding, Mello Leitão included a possible schedule for breastfeeding as well as tables indicating the appropriate amount of milk during the baby's first fourteen months. ${ }^{50}$ Similarly, when Jesuit scholastic Júlio Marinho (1891-1976) wrote about education, his main concern was to give useful advice to elementary and secondary teachers on topics such as the prevention of nearsightedness and the manufacture of student desks. ${ }^{51}$

\subsection{Science and Religion}

In 1909, Silva Tavares created a section entirely dedicated to the natural sciences and religion. ${ }^{52}$ This section aimed to scrutinize the conflict thesis between science and religion by addressing the scientific plausibility of the theory of evolution and its epistemological value. ${ }^{53} \mathrm{He}$ wanted to provide a resolute answer to a fundamental question: "Can a Catholic admit evolution without compromising his faith?" ${ }^{4}$ Later that year, German Jesuit Ambros Schupp (1840-1914) made a first attempt to answer the question. ${ }^{55} \mathrm{He}$ began by explaining the difference between Darwinism and evolution, because the two terms were often used interchangeably, which "originated pitiful errors" for Christian "religion and morals." ${ }^{\text {. }}$ After delving into the crucial concepts of species, constancy, evolution, and the survival of the fittest, Schupp asserted

50 Cândido de Mello Leitão, "Alimentação da Criança nos primeiros tempos da vida," BVC 10 (1912): 173-88.

51 Júlio Marinho, "A miopia escolar," BVC 15 (1917): 217-23; Marinho, "Higiene escolar," BVC 13 (1915): 206-9; 247-52; Marinho, "Higiene escolar," BVC 14 (1916): 47-49; Marinho, "Mobiliário escolar," BVC 19 (1921): 211-16.

$5^{2}$ Joaquim da Silva Tavares, "As sciencias naturais e a religião," BVC 8 (1909): 33-35.

53 The literature on the history of the relationship between science and religion is particularly extensive. See especially the classic study by John Hedley Brooke, Science and Religion: Some Historical Perspectives (Cambridge: Cambridge University Press, 1991), as well as the more recent Peter Harrison, The Territories of Science and Religion (Chicago: Chicago University Press, 2015). Because they offer a broad range of scholarly contributions on the relationship between science and religion, the following edited volumes can also be extremely helpful: Ronald L. Numbers, ed., Galileo Goes to Jail and Other Myths about Science and Religion (Cambridge, MA: Harvard University Press, 2010); Harrison, Cambridge Companion to Science and Religion; and Gary B. Ferngren, ed., Science and Religion: A Historical Introduction (Baltimore: John Hopkins University Press, 2017). Tavares, "As sciencias naturais e a religião," 35.

55 Ambrósio Schupp, "A evolução e o homem," BVC 8 (1909): 81-94; 147-63.

56 Schupp, "A evolução e o homem," 81. 
that Charles Darwin (1809-82) had written a "most remarkable work." ${ }^{57} \mathrm{Al}-$ though he was definitely not an enthusiastic supporter of a purely mechanistic explanation, Schupp believed that Darwinism had been "a powerful incentive for the progress of science. 58

For Schupp, there were three arguments that supported the evolution of species: the evolution of the Solar System; the evolution of the Earth's crust; and the existence of fossils. Especially favorable to Darwin's theory were the adaptation of species to climate changes and the artificial selection of species. ${ }^{59}$ His main critique was not on the evolution of species but rather on the origin of species. He claimed that there was no scientific basis to state that all species had originated from a few lifeforms, let alone from a single organism, as Ernst Haeckel (1834-1919) contended, because doing so contradicted the universally accepted axiom omne vivum ex vivo (all life is from life)..$^{60}$ Because Schupp believed that the theory of natural selection did not explain animal symmetry, the development of sensorial organs, or the existence of two genders, among other crucial issues, he advocated for theistic evolution, as proposed by many nineteenth-century Christian thinkers. ${ }^{61}$ In Schupp's words, the belief in a "most intelligent being that governed the world wisely according to certain plans" easily conceded the "evolution of all organisms" in perfect "harmony with the doctrines of [Christian] faith." ${ }^{2}$ While reminding his

57 Schupp, "A evolução e o homem," 84.

58 Schupp, "A evolução e o homem," 84.

59 Schupp, "A evolução e o homem," 87-88.

6o Schupp, "A evolução e o homem," 89-9o.

61 On the reception of Darwinism in the late nineteenth and twentieth century, see especially the classic works by Peter Bowler, James R. Moore, and Ronald L. Numbers: Peter J. Bowler, The Eclipse of Darwinism: Anti-Darwinian Evolution Theories in the Decades around 1900 (Baltimore: Johns Hopkins University Press, 1983); James R. Moore, The PostDarwinian Controversies: A Study of the Protestant Struggle to Come to Terms with Darwin in Great Britain and America, 1870-1900 (New York: Cambridge University Press, 1979); Ronald L. Numbers, The Creationists: From Scientific Creationism to Intelligent Design (Cambridge, MA: Harvard University Press, 2006). For an introduction to the topic, see Peter J. Bowler and John Henry, "Evolution," in Ferngren, Science and Religion, 204-19; Jonathan Hodge, "Evolution," in The Cambridge History of Science, Vol. 6: Modern Biological and Earth Sciences, ed. Peter J. Bowler and John V. Pickstone (Cambridge: Cambridge University Press, 2009), 242-64; James R. Moore, "Religion and Science," in Bowler and Pickstone, Cambridge History of Science, 6:541-62.

62 Schupp, "A evolução e o homem," 148. 
readers that evolution was not contrary to Christian faith, and that Darwinism had not been condemned by the Catholic Church, the German Jesuit insisted that man was not only "the end result of a phylogenetic or ontogenetic evolution of species" but the final cause of the evolution of nature. ${ }^{63}$

Although it initially seemed promising, this section of the journal fell short of its ambitious program. After Schupp's article, Vulgarização científica only published four other essays promoting a compatibilist vision of science and religion. ${ }^{64}$

4

Conclusion

Because they were especially concerned with funding Botânica and Zoologia, the Portuguese Jesuits published a popular scientific journal for eighteen consecutive years, and the success of Vulgarização cientifica may have inspired other provinces to follow their example. In 1913, for example, the Spanish Jesuits from the Observatorio del Ebro emulated their Portuguese companions by publishing Ibérica (1913-36 and 1945-2004), a weekly magazine devoted to "general scientific culture,"65 the principal objective of which, namely making "science accessible to everyone," was encapsulated in its subtitle: "El progreso de las ciencias y de sus aplicaciones" (The progress of science and its applications). Ibérica went on to become one of the most important popular scientific journals in Spain with articles on physics, astronomy, meteorology, seismology, and geophysics. ${ }^{66}$

63 Schupp, "A evolução e o homem," 153. On the reception of Darwinism by the Roman Catholic Church in the first decades after the publication of On the Origin of Species (1859), see especially Mariano Artigas, Thomas F. Glick, and Rafael A. Martínez, Negotiating Darwin: The Vatican Confronts Evolution, 1877-1902 (Baltimore: Johns Hopkins University Press, 2006).

64 F. de Mello, "A propósito de aviação," BVC 9 (1910): 36-41; Camilo Torrend, "Origem da cellula: Geração espontanea" BVC 15 (1917): 247-53; Torrend, "Origem da cellula: Geração espontanea," BVC 16 (1918): 103-10; Raúl Dias Sarreira, "A propósito de um livro recente: A. Emyieu, La part des croyants dans les progrès de la science au XIXe siècle," BVC 19 (1921): $184-87$.

65 Ricard Cicera, "La ciencia al alcance de todos," Ibérica Spécimen A (1913): 1-5, here 1.

66 Although it shared certain similarities with Vulgarização científica, the journal was primarily aimed at a non-specialist readership, and hence differed from Brotéria's research series Botânica and Zoologia. On the history of the Observatorio del Ebro and the journal Ibérica, see Josep Battló and David Altadill, "The Ebre Observatory: Its Path to Ionospheric Research," Advances in Space Research 39 (2007): 941-46; Nestor Herran, "Science to the 
In 1925, Silva Tavares broadened the aims of Vulgarização científica, transforming it into a cultural, philosophical, and humanistic periodical. Like Vulgarização científica, the so-called cultural Brotéria was published alongside the scientific series. ${ }^{67}$ However, the main objective behind its creation was not the popularization of science, nor the funding of Botânica and Zoologia, but rather to communicate the Christian faith and Christian values to a broad yet learned audience. The Jesuits argued that the restructuration of Vulgarização científica and the creation of a monthly review was intended to accommodate their readers' pleas to address a larger number of topics, which would indeed contribute to a "greater social good."68 Thus, in the pages of cultural Brotéria, the Jesuits sought to publish articles on literature, sociology, philosophy, theology, and history. Given the diversity of the subjects it covered, and its apologetic program, the cultural Brotéria shared many common features with the other learned journals published by the Society of Jesus all over the world. Whether Silva Tavares's decision represented the failure of his strategy to secure funding for the scientific series, or whether it was instead an effort to publish a magazine similar to other Jesuit periodicals, remains unclear.

Cultural Brotéria published works by Jesuits and lay authors, but the vast majority of essays were by Portuguese Jesuits such as Manuel Antunes (191885), António Leite (1911-2004), Domingos Maurício (1896-1978), and João Pereira Gomes (1917-2002), to name only a few. ${ }^{69}$ Although cultural Brotéria had an exceptional longevity in the Portuguese context, only a few historians have delved into its history. However, the significance of the cultural series can easily be grasped by its popularity among both liberal and conservative thinkers. In the centennial celebration of Brotéria, thirty-eight personalities

Glory of God': The Popular Science Magazine Ibérica and Its Coverage of Radioactivity," Science and Education 21 (2012): 335-53; Pascual Bolufer, "Science and Technology in the 2oth Century as Seen through the Journal Ibérica (1914-2003)," Contributions to Science 7 (2011): 185-90; Maria Genescà-Sitjes, "Ibérica Magazine (1913-2004) and the Ebro Observatory," Contributions to Science 9 (2013): 159-68.

67 Although it is simply referred to as cultural Brotéria, this journal was published under a variety of subtitles: Fé: Ciências; Letras (1925-31); Revista contemporânea de cultura (193264); Revista de cultura (1965-69); Cultura e informação (1970-99); Revista de cultura (19992000); Cristianismo e cultura (2001-).

68 "A servir de prólogo nesta segunda série," Brotéria: Fé; Sciências; Letras 1 (1925): 5-6, here 5.

69 For critical editions of the work of Manuel Antunes and João Pereira Gomes, see José Eduardo Franco, ed., Obra completa do Padre Manuel Antunes, 14 vols. (Lisbon: Fundação Calouste Gulbenkian, 2007-12); and Henrique Leitão and José Eduardo Franco, eds., Jesuítas, ciência e cultura em Portugal: Obra selecta do Pe.João Pereira Gomes S.J. (Lisbon: Esfera do Caos, 2012). 
from the political, clerical, and academic spheres - including two former presidents, two bishops, and the patriarch of Lisbon-paid tribute to the Jesuit journal. ${ }^{70}$ Regardless of creed or political stance, they celebrated the Jesuits' work in creating an exceptional cultural journal.

One year after the foundation of the cultural Brotéria, the political situation in Portugal changed once again when a military coup on May 28, 1926 overthrew the republican government, banned all political parties, and laid the groundwork for the foundation of the forty-year dictatorial regime of the Estado Novo. Because it published some speeches by Prime Minister António de Oliveira Salazar (1889-1970, in office 1932-68), the cultural Brotéria seemed to support the dictatorship, especially until the $1960 .^{71}$ Unlike the First Republic, Estado Novo was particularly supportive of the Jesuits and their educational work. As well as reversing the Jesuits' exile, the new regime worked extensively on reestablishing diplomatic relations with the Holy See, the high point of which was the 1940 concordat that restored the Catholic Church some-but not all—of its former privileges. ${ }^{72}$ In harmony with the propaganda of the Estado Novo, Brotéria also participated in the political celebrations of both the foundation of Portugal (1140) and the country's independence from Spanish rule (1640). $\cdot{ }^{73}$ Between 1939 and 1940, the editorial team of Brotéria celebrated not only the national jubilees but also its own four-hundredth anniversary. ${ }^{74}$

In the following decades of the regime, the cultural Brotéria underwent a few additional changes. Beginning in 1945, the Jesuits created a section dedicated to philosophy that was later expanded into an independent magazine in

70 On the appraisal of the cultural Brotéria, see Rico and Franco, Fé, ciência, cultura, 19-86.

71 José Eduardo Franco, "A evolução editorial da Brotéria," in Rico and Franco, Fé, ciência, cultura, 103-26, here 116-17.

72 On the history of the diplomatic relations between the Estado Novo and the Catholic Church, see especially Manuel Braga da Cruz, O Estado Novo e a Igreja Católica (Lisbon: Bizâncio, 1998).

73 The peak of the political celebrations was, undoubtedly, the design of a monumental exhibition in Lisbon in 1940. On the role of the Portuguese World Exhibition in commemorating the new regime, see especially Margarida Acciaiuoli, Exposições do Estado Novo, 1934-1940 (Lisbon: Livros Horizonte, 1998); David Corkill and José Carlos Pina Almeida, "Commemoration and Propaganda in Salazar's Portugal: The 'Mundo Português' Exposition of 1940," Journal of Contemporary History 44 (2009): 381-99, and Ellen W. Sapega, Consensus and Debate in Salazar's Portugal: Visual and Literary Negotiations of the National Text, 1933-1948 (University Park, PA: Pennsylvania State University Press, 2008).

74 For the celebration of the foundation of Portugal and independence from Spanish rule, see the issue of January 1939. For the celebration of the anniversary of the foundation of the Society of Jesus, see the issue of November 1940. 
1947, the Revista portuguesa de filosofia (Portuguese journal of philosophy). ${ }^{75}$ In the period following Vatican II (1962-65), the cultural Brotéria significantly broadened its scope and started publishing subtle critiques of the political, economic, social, and educational policies of the Estado Novo. ${ }^{76}$ Twenty years later, Superior General Peter-Hans Kolvenbach (1928-2016, in office 1983-2008) sought to standardize the cultural journals published by the Society all over the world. In 1984, he addressed the editorial team of Brotéria and reminded them that the main objective of the journal should be "to deepen and announce the whole truth" to a learned Christian audience, ${ }^{77}$ and because it played a crucial role in the "permanent formation of intellectual elites," Brotéria should place Christian faith and values at its core.

75 Lúcio Craveiro da Silva, "A Faculdade de Filosofia de Braga e a sua Revista portuguesa de filosofia: Mensagem e evolução," Revista portuguesa de filosofia 51 (1995): 281-94.

76 Franco, "A evolução editorial da Brotéria," 119.

77 Peter Hans Kolvenbach, "Função de uma revista de cultura," Brotéria 118 (1984): 483-84, here 483 . 